\title{
Bacterial Clearance in Patients with Lepromatous Leprosy not receiving Treatment
}

\author{
S. G. BROW NE, O.B.E., M.D., F.R.C.P., F.R.C.s., D.T.M. \\ L.eprosy Service Research Unit, Uzuakoli, Eastern Nigeria
}

While the search must continue for a drug that possesses potent and rapid bactericidal or bacteriostatic activity in leprosy - a kind of therapia sterilisans magna (Ehrlich) - it seems apposite to emphasize one aspect of the problem that may point the way to therapeutic advance, that is, the capacity of the tissues to deal unaided with non-viable Myco. leprae.

Some authorities have held that treatment should be continued as long as any acid-fast material can be detected in routine smears, and treatment for life is often advocated for patients who have had lepromatous or borderline leprosy. While we should never throw caution to the winds and by unorthodox advice put both the patient and his entourage at risk, it might be possible to discontinue anti-leprosy treatment when viable $M y c o$. leprae are no longer present in the skin or in deep tissue reservoirs.

In the presulphone days, the gradual disappearance of Myco. leprae from the skin was sometimes observed. When today leprosy treatment cannot be continued because of persistent exacerbation, psychosis, etc., the elimination of fragmented bacilli may proceed as if treatment were being given. The following case report, drawn from a series of eight patients with lepromatous leprosy in whom non-viable $M y c o$. leprae were progressively eliminated when no treatment was being given, may serve as an example.

\section{Case report}

The history of a patient at the Ekpene Obom Leprosy Settlement, Qua Iboe Mission, Eastern Nigeria, under the care first of Dr Oswald Mitchell, F.R.C.s.E., and subsequently of Dr E. M. Davis, has been studied recently. Because of persistent psychosis, anti-leprosy treatment was stopped, but fragmented Myco. leprae continued to disappear from the eight sites (skin, ear-lobes and nasal mucosa) regularly examined.
The patient was a woman, aged about 40, suffering from severe long-standing lepromatous leprosy, macular and nodular. The main peripheral nerve trunks were enlarged and tender, and neuropathic ulceration was present on the left forefoot. On admission, the Bacterial Index (B.I.) was $3 \cdot 4$ (maximum 4.o, on Dharmendra's notation), and the proportion of solid rods was low, being only i 6 per cent. The patient denied all previous treatment.

She was given dapsone, roo mg. twice weekly initially, increasing to $200 \mathrm{mg}$. twice weekly. After I 8 months' treatment, she experienced a moderately severe psychotic episode, probably attributable to the combined effects of personality predisposition and environment. By this time, the B.I. had fallen to 2.6 , the remaining solid rods having disappeared some three months previously from all sites smeared. Dapsone was suppressed.

Psychosis rapidly supervened when dapsone was cautiously given in $25 \mathrm{mg}$. doses, and the drug was again discontinued. In spite of the absence of all anti-leprosy treatment for io months, the B.I. continued to fall. Acid-fast material was no longer present in smears taken from the skin, and those from the ear-lobes and nasal mucosa showed only very degenerate bacilli and scattered collections of acid-fast dust.

When treatment was again resumed with dapsone (25 mg. twice-weekly), clinical and bacteriological progress continued at the same rate and the remaining acid-fast material disappeared from the ear-lobes and septal mucosa in the course of the next eight months. Treatment thereupon had again to be suppressed by reason of psychosis, but all smears have since remained consistently negative.

\section{DISGUSSION}

The rate of disappearance of degenerate and non-viable forms of Myco. leprae appears to de- 
pend on some factor or factors other than the bactericidal or bacteriostatic activity of a drug. It apparently cannot be increased beyond a certain norm for the individual. Dapsone, thiambutosine, ditophal, B 663 and some other drugs can be shown to ensure a roughly comparable speed of reduction in the proportion of 'solid rods' (or viable forms of Myco. leprae), but the time taken for the removal of the last vestiges of acid-fast material from the tissues is variably protracted, and during this time the patient is subject to the risk of tissue sensitivity phenomena.

While some workers go so far as to insist on a positive Mitsuda reaction before considering that a patient who has had lepromatous leprosy can be allowed to return to the community, in our experience the lepromin test remains negative after clinical arrest and when all acid-fast material has disappeared from the skin and nasal mucosa.

Examination of tissue removed by needle biopsy from deep organs (e.g. liver) may furnish evidence of the persistence of viable Myco. leprae when they have long since disappeared from superficial sites, but this procedure is not generally practicable.

It is hoped that the recording of this representative history, may stimulate the reporting of other instances in which bacterial clearance of fragmented Myco. leprae has proceeded satisfactorily in the absence of anti-leprosy treatment. It may one day be possible to determine in what circumstances it would be justifiable to withhold treatment in patients suffering from tissue reaction to mycobacterial breakdown products rather than from infection with viable and multiplying Myco. leprae.

\section{S U M M A R Y}

The progressive disappearance from the skin and nasal mucosa of non-viable Myco. leprae in a patient suffering from lepromatous leprosy but not receiving anti-leprosy treatment is recorded. Dapsone was stopped because of severe recurrent psychosis, but clinical and bacteriological improvement continued as when the patient was receiving anti-leprosy drugs.

\section{A GKNOWLEDGEMENTS}

My grateful thanks are due to Dr E. M. Davis for calling my attention to this patient, and to Dr S. O. Egwuatu, Chief Medical Officer, Ministry of Health, Eastern Nigeria, for permission to publish this article. 